dr inz. Stanistaw Bocian

mgr in.̇. Jerzy Frączek

Instytut Pojazdów Szynowych „,TABOR '

\title{
Program do badań układu sterująco - pomiarowego, pracującego w sieci CANopen, przeznaczonego do pojazdu szynowego
}

\begin{abstract}
$W$ artykule opisano program do badania uktadu sterujaco - pomiarowego pracujacego $w$ sieci CANopen. Wykorzystano do tego język programowania ogólnego (język $C++$ ). Przez autorów artykulu zostały zrealizowane funkcje dotyczqce sieci CANopen zwiazane z konfiguracja $i$ monitorowaniem pracy $w$ sieci oraz funkcje zwiazane $z$ uruchomieniem programów badawczych. Przedstawiono przykład uruchamiania programu sterujacego hamulcem pneumatycznym pojazdu szynowego z wykorzystaniem 12 - pozycyjnego zadajnika. Praca jest kontynuacja artykułu „Przyszłościowe współbieżne mikroprocesorowe inteligentne systemy mechatroniczne w sterowaniu $i$ diagnostyce pojazdów szynowych" przedstawionego w czasopiśmie „Pojazdy Szynowe” 4/2007; 1/2008; 2/2008. Artykut powstat w wyniku realizacji projektu badawczego KBN 4T $12 C 04929$ pt." Rozproszone wspótbieżne mikroprocesorowe inteligentne podsystemy mechatroniczne w sterowaniu i diagnostyce pojazdów szynowych".
\end{abstract}

\section{Wprowadzenie}

W pracach [1, 2, 3 i 4] przedstawiono wiadomości na temat sieci CAN. W artykule opisano

program Copen zrealizowany przez autorów artykułu, spełniający rolę pomocniczą przy tworzeniu i badaniu algorytmów sterująco - pomiarowych. Algorytmy te mają być realizowane przez układy komputerowe pracujące w sieci CANopen.

Docelowy układ może składać się np. z kosztownych sterowników i komputerów przemysłowych, dlatego korzystne jest wstępne dopracowanie algorytmu przy wykorzystaniu sprzętu PC powszechnego użytku.

Funkcje programu dzielą się zasadniczo na dwie grupy:

- funkcje dotyczące sieci CANopen związane z konfiguracją i monitorowaniem pracy sieci

- funkcje związane $\mathrm{z}$ uruchamianiem programów badawczych.

Typowy komputer PC, aby mógł współpracować z siecią CAN (która jest podstawą standardu CANopen), musi być wyposażony w sprzęg do tej sieci. Obecnie program może korzystać $\mathrm{z}$ trzech rodzajów sprzęgów. Są to konwertery:

- USB / CAN, typu USB-8473 firmy National Instruments

- RS232 / CAN, typu i-7530 (Tech base)

- PCMCIA / CAN, typu CANcardXL firmy Vector Informatik.

Wyboru typu sprzęgu dokonuje się przy starcie programu, co pokazuje rys. 1.

Możliwe do wyboru są te pozycje, które są aktualnie zainstalowane w komputerze.

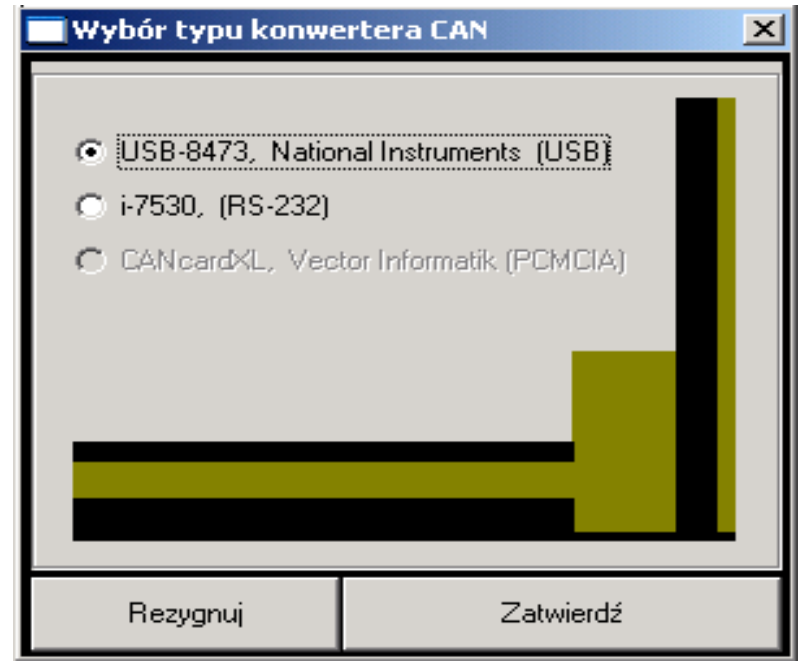

Rys. 1. Okno wyboru typu złącza CAN

Po dokonaniu wyboru mamy na ekranie okno główne przedstawione na rys. 2. Funkcje dotyczące sieci są dostępne przez menu "Sieć", a funkcje programów badawczych przez menu "Programy".

\section{Funkcje konfiguracyjne programu}

Funkcje dotyczące konfiguracji, testowania i monitorowania sieci są skupione w oknie otwieranym z menu: Sieć | Konfiguracja (rys. 2). Funkcje są pogrupowane na oddzielnych kartach odpowiednio do serwisów CANopen: NMT, SDO, PDO. Serwisy CANopen są omówione w [2]. Karty Can1 i Can2 służą do monitorowania sieci na poziomie komunikatów CAN. 


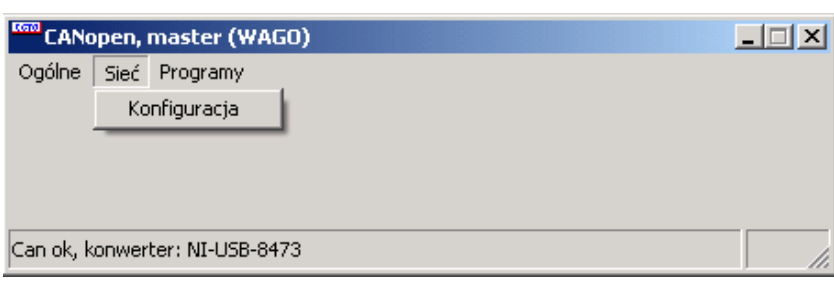

Rys. 2. Okno główne programu

\subsection{Serwis NMT}

Karta Nmt (rys.3) pozwala na wykonywanie przez program funkcji mastera serwisu: Network Management (NMT). W każdej sieci CANopen musi być węzeł pełniący taką funkcję. Aby wykonać operację należy wybrać adres węzła slave (Slv ID), funkcję (Start remote node, ...) i wysłać komunikat naciskając klawisz Tx.

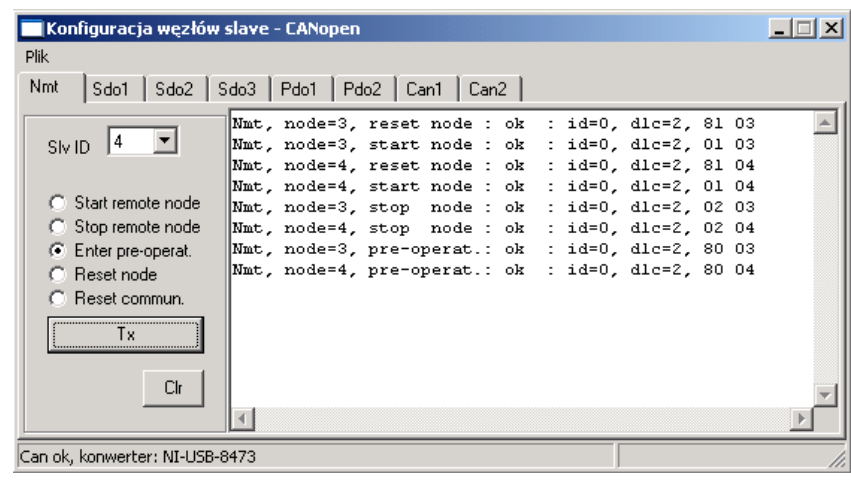

Rys. 3. Karta serwisu: Network Managment (NMT)

\subsection{Serwis SDO}

Karty Sdo1, Sdo2, Sdo3 (rys. 4, 5, 6) pozwalają na wykonywanie przez program funkcji klienta serwisu: Service Data Objects (SDO). Serwis SDO służy do konfiguracji słownika obiektów węzłów slave. Funkcje polegają na odczycie (Upload) i zapisie (Download) pozycji słownika.

Poszczególne pozycje słownika są określone przez indeks i subindeks i mogą zawierać dane złożone z 1 .. 8 bajtów. Karta Sdo1 pozwala na dostęp do dowolnej pozycji słownika. Aby odczytać pozycję należy podać indeks i subindeks i kliknąć: Upload. Aby zapisać pozycje należy dodatkowo podać liczbę zapisywanych bajtów (pole Dlc) oraz ich wartości (pola D1 .. D8). Aby korzystać z tej karty trzeba znać szczegółowy opis pozycji słownika obiektów zawarty np. w opisach standardu CANopen [4], [5] lub w dokumentacji konkretnego węzła slave.

$\mathrm{W}$ polu informacyjnym pokazywana jest wymiana komunikatów w ramach każdej operacji SDO. Przez tx: oznaczone są komunikaty wysyłane, przez rx: odbierane

Karty Sdo2 i Sdo3 ułatwiają wykonywanie wybranych operacji SDO. Modyfikowane parametry są przedstawione w sposób wygodny dla

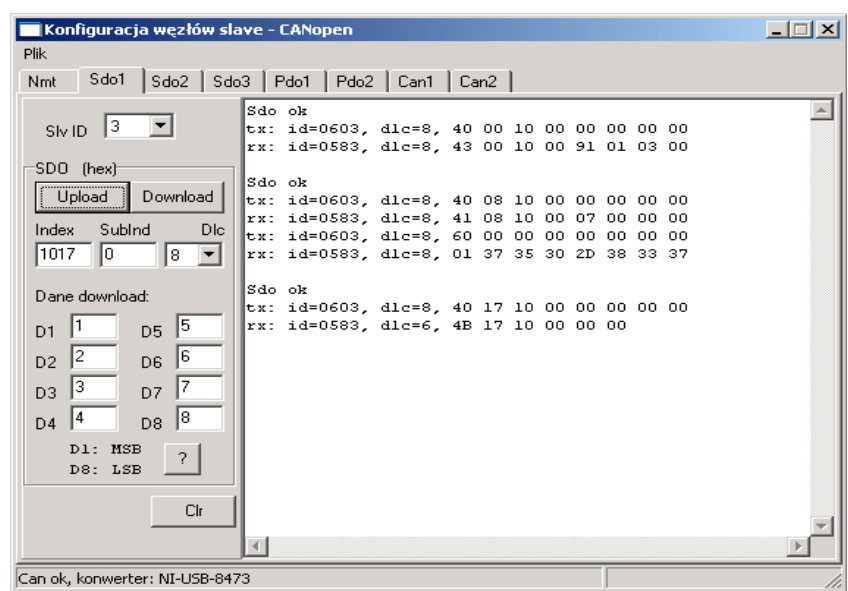

Rys. 4. Karta ogólna serwisu Service Data Objects (SDO).

użytkownika. Ustalenie indeksu, subindeksu i zestawu bajtów danych wykonuje program. Przykładem na karcie Sdo2 rys. 3 jest parametr Heartbeat producer [2], związany z kontrolą poprawności pracy sieci. Parametr ten ustala odstęp czasowy wysyłania kolejnych komunikatów Heartbeat przez węzeł slave. Należy tylko podać czas $\mathrm{w}$ ms i kliknąć klawisz: Ustaw.

Karta Sdo3 rys. 6 zawiera elementy związane $\mathrm{z}$ konfiguracją obiektów PDO (transmisja danych procesowych). Zadanie obejmuje ustalenie parametrów mapowania (powiązania danych PDO z odpowiednimi pozycjami słownika obiektów węzła slave) i parametrów komunikacyjnych obiektów PDO [2]. Konfiguracja PDO jest konieczna, gdy domyślny zdefiniowany $\mathrm{w}$ [4] układ PDO jest w danym zastosowaniu niewystarczający. W szczególności potrzeba taka zachodzi. gdy oprócz stanów wejść i wyjść fizycznych należy przesyłać między węzłami wartości zmiennych obliczeniowych. W takiej sytuacji należy ustalić rozszerzony układ identyfikatorów COB-ID dla obiektów PDO. W [3], p.4.2 przedstawiono przykład takiego układu. Elementy na karcie Sdo3

rys. 6 ułatwiają konfigurację według powyższego układu.

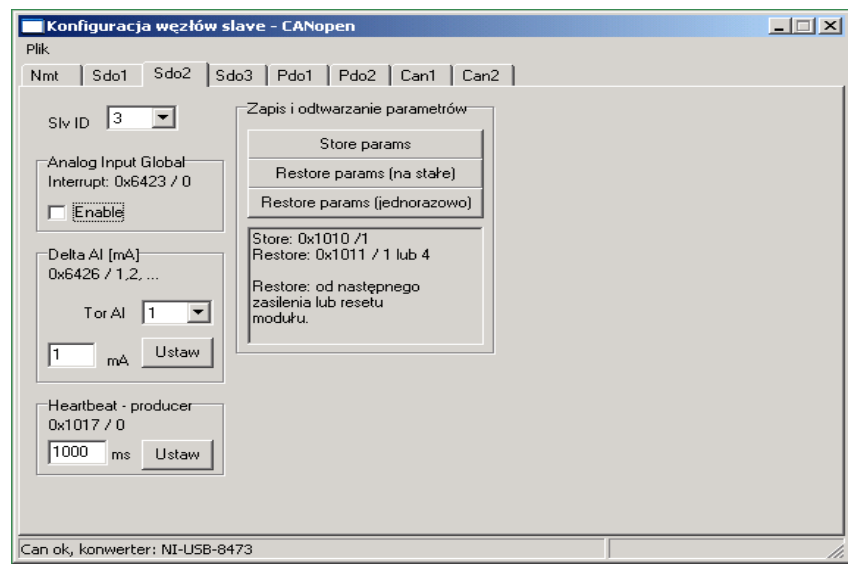

Rys. 5. Karta wybranych funkcji serwisu Service Data Objects (SDO) 


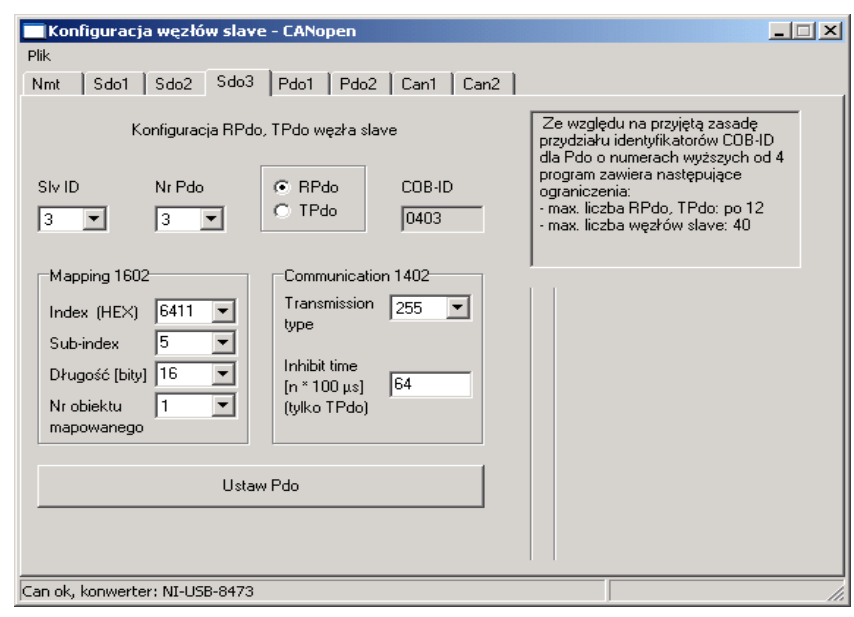

Rys. 6. Karta serwisu Service Data Objects (SDO) dla konfiguracji obiektów PDO

\subsection{Serwis PDO}

Serwis Process Data Objects (PDO) służy do transmisji danych procesowych podczas normalnej pracy węzła za pomoca objektów PDO. Karta Pdo1 (rys. 7) służy do wysłania i odbierania obiektów PDO. Przy wysłaniu należy podać adres węzła slave, numer PDO, liczbę wysyłanych bajtów (Dlc) i wartość bajtów (pola D1 .. D8). Program ustala identyfikator komunikatu (COB-ID) przy czym dla PDO nr $1 . .4$ według domyślnego układu identyfikatorów [4] a dla pozostałych według wspomnianego wcześniej układu przykładowego [3], p.4.2.

$\mathrm{W}$ polu informacyjnym górnym pokazywane są wysyłane komunikaty określane jako TPDO. W polu dolnym pokazywane są odbierane przez program obiekty określone RPDO.

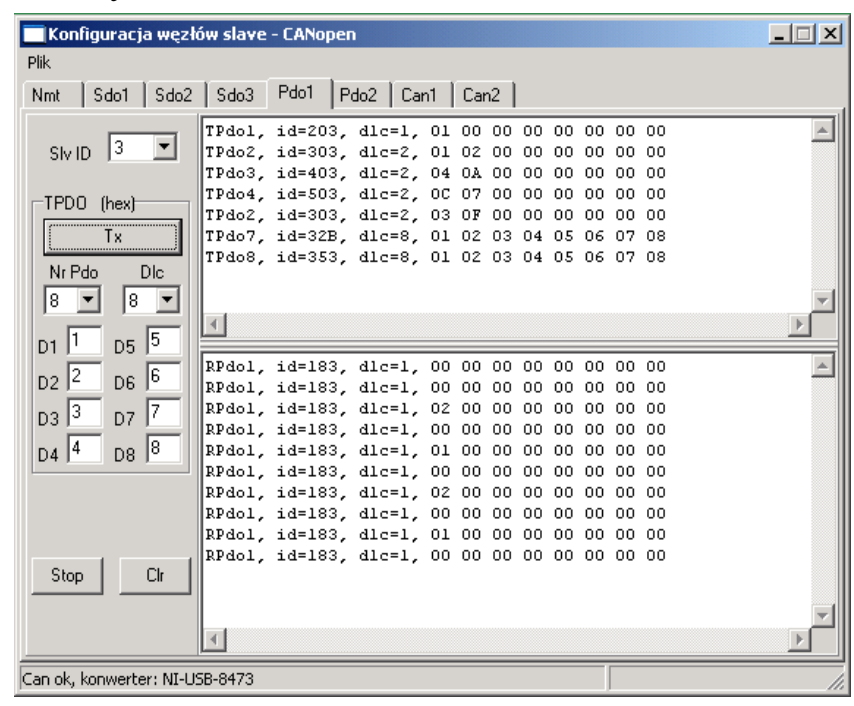

Rys. 7. Karta ogólna serwisu Process Data Objects (PDO)

Karta Pdo2 (rys. 8) obsługuje wybrane obiekty PDO w sposób wygodny dla użytkownika. Obsługa dotyczy czterech wejść i czterech wyjść binarnych oraz dwóch wejść i dwóch wyjść analogowych.

Jednocześnie można obsługiwać do czterech węzłów slave o wybranych adresach (Slv ID).

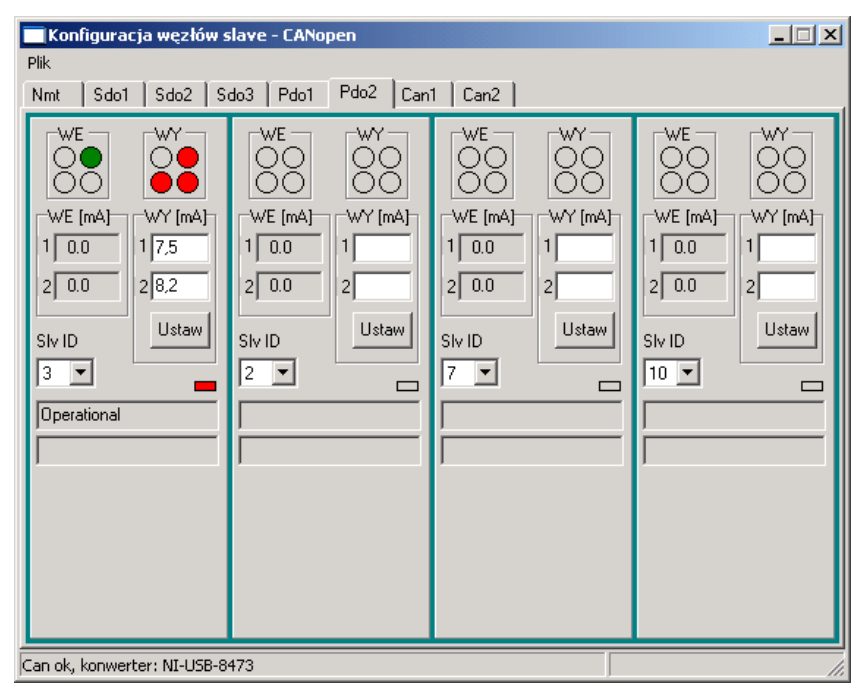

Rys. 8. Karta pomocnicza serwisu Process Data Objects (PDO)

\subsection{Transmisja CAN}

Na karcie Can1 (rys. 9) można wysłać i odebrać dowolny komunikat CAN. Komunikaty są prezentowane odpowiednio $\mathrm{w}$ górnym i dolnym polu informacyjnym. Dla komunikatów odbieranych można zastosować jednozakresowy filtr powodujacy pomijanie pewnego zakresu identyfikatorów.

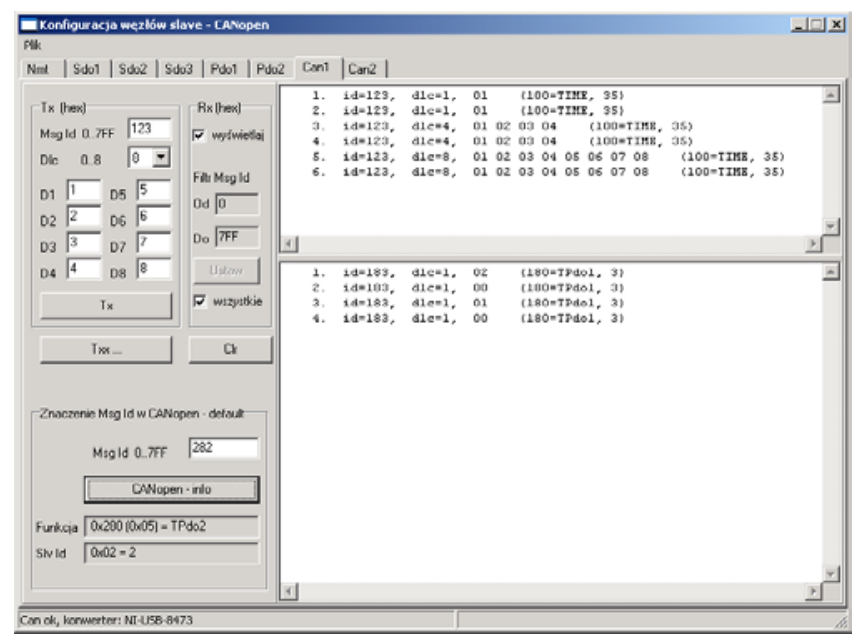

Rys. 9. Karta wysyłania i odbierania komunikatów CAN

Karta Can2 (rys. 10) służy do prezentacji odbieranych komunikatów CAN. W odróżnieniu od karty Can1 komunikaty o tym samym identyfikatorze są prezentowane $\mathrm{w}$ tym samym wierszu zawierającym licznik odebranych komunikatów (kolumna N).

\section{Funkcje badawcze programu}

Program Copen zawiera program badawczy: Hamowanie 1. Algorytm tego programu jest omówiony $\mathrm{w}$ [3]. W skrócie algorytm polega na realizacji hamowania sterowanego 12 - pozycyjnym zadajnikiem. Hamowanie składa się z zadanej liczby odcinków 


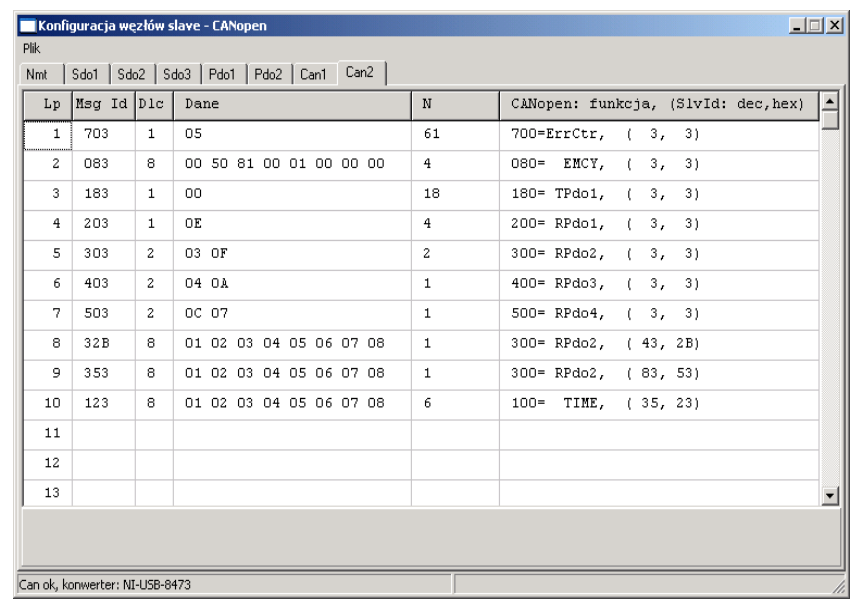

Rys. 10. Karta dodatkowa dla prezentacji odbieranych komunikatów CAN

hamowania o zadanym czasie trwania. Na każdym odcinku załączona jest wybrana pozycja zadajnika hamowania. Układ hamulcowy jest sterowany dwoma zaworami sterowanymi analogowo napięciem 0 .. $10 \mathrm{~V}$. Jeden z zaworów podnosi ciśnienie w układzie, a drugi opuszcza według ustalonego algorytmu [3].

\subsection{Przygotowanie programu badawczego}

Można przygotować dowolna liczbę zestawów danych i wykonywać program z tym zestawem wielokrotnie. Okno na rys. 11 służy do organizowania i uruchamiania programu $\mathrm{z}$ poszczególnymi zestawami danych.

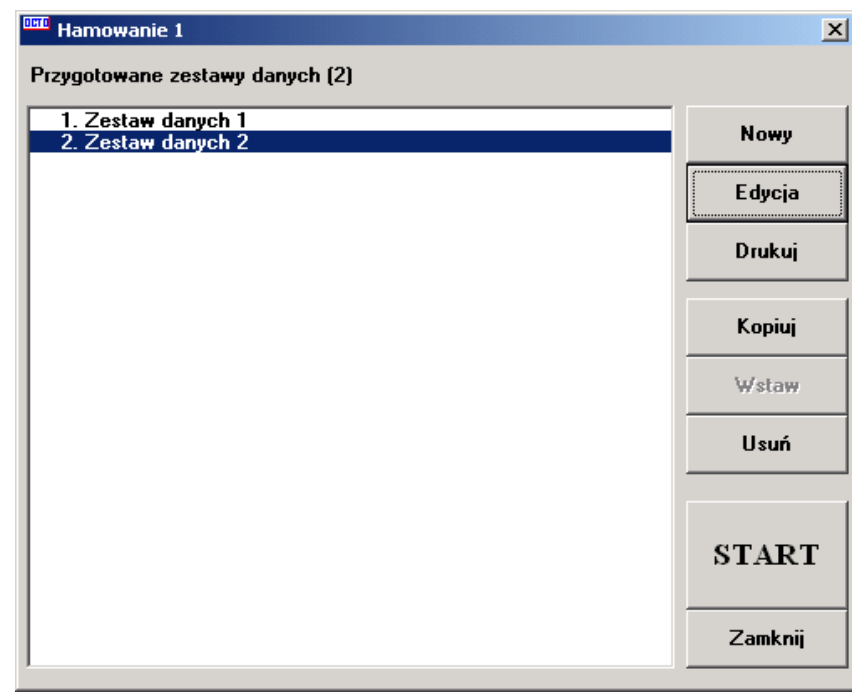

Rys. 11. Okno organizowania zestawów danych i uruchamiania programów badawczych

Przygotowanie poszczególnych zestawów danych odbywa się w kolejnym oknie (rys. 12). Po ustaleniu liczby odcinków programu dla każdego odcinka ustala się czas jego trwania (t_odc) i wybiera $\mathrm{z}$ listy pozycję zadajnika hamowania.

\begin{tabular}{|c|c|c|c|}
\hline \multicolumn{4}{|c|}{ 四 Zestaw danych programu: Hamowanie 1} \\
\hline 2 & \multicolumn{3}{|c|}{ Zestaw danych 2} \\
\hline \multicolumn{4}{|c|}{ Parametry odcinków } \\
\hline \multicolumn{2}{|c|}{ Liczba odcinków } & \\
\hline 10 & zatwierdź & & $\begin{array}{l}C \text { Luzow. wys. cisn. }(L W] \\
C \text { Wyrównanie }(W)\end{array}$ \\
\hline Nr odcinka & Poz. NH & t_odc[s] & $\begin{array}{l}C \text { Napełnianie }[\mathbb{N}] \\
\text { C. Gotowosc }[\mathrm{G}]\end{array}$ \\
\hline 1 & HS1 & 10 & \multirow{2}{*}{ C. Hamow. stużbowe 1 (HS1) } \\
\hline 2 & $\mathrm{HS2}$ & 15 & \\
\hline 3 & $\mathrm{HS} 3$ & 10 & $\begin{array}{l}\text { Hamow. stuzbowe } 2 \text { (HS2) } \\
\text { Hamow. stuzbowe } 3 \text { (HS3) }\end{array}$ \\
\hline 4 & $\mathrm{HS4}$ & 20 & C Hamow stuzibowe 4 [HS4] \\
\hline 5 & HS5 & 2.5 & C Hamow. stużbowe 5 (HS5) \\
\hline 6 & HS6 & 2.5 & \\
\hline 7 & HS7 & 7 & C Hamow. stużbowe 7 (HS7) \\
\hline 8 & HS8 & 7.8 & \\
\hline 9 & HS1 & 4 & \\
\hline 10 & HS9 & 12 & \\
\hline & & & C Hamow. stużbowe 12 (HS12) \\
\hline & & & $\begin{array}{l}C \text { Hamow. stużbowe } 12 \text { (HS12) } \\
C \text { Hamowanie nagke }(\mathrm{HN})\end{array}$ \\
\hline \multicolumn{2}{|c|}{ Zatwierdź } & Rezygnuj & \\
\hline
\end{tabular}

Rys. 12. Okno przygotowania danych programu Hamowanie 1

Algorytm regulacji ciśnienia jest określony zestawem parametrów ustalanych wspólnie dla wszystkich zestawów danych w oknie pokazanym na rys. 13.

\begin{tabular}{|c|c|c|}
\hline \multicolumn{2}{|c|}{ Parametry hamowania } & \\
\hline \multicolumn{2}{|c|}{ 1. gradient ciśnienia dla stopnia hamow. $1[\mathrm{kPa} / \mathrm{s}]$} & 200 \\
\hline \multicolumn{2}{|c|}{ 2. gradient ciśnienia dla stopnia hamow. $2.12[\mathrm{kPa} / \mathrm{s}]$} & 18,5 \\
\hline \multicolumn{2}{|c|}{ 3. gradient ciśnienia przy luzow. podczas hamow. stużb. [kPa/s] } & 100 \\
\hline \multicolumn{2}{|c|}{ 4. nominalna wartość ciśnienia w przewodzie głównym [kPa] } & 500 \\
\hline \multicolumn{2}{|c|}{ 5. przyrost ciśnienia na pierwszym stopniu luzowania [kPa] } & 25 \\
\hline \multicolumn{2}{|c|}{ 6. wartość 1 ciśn. przy luzowaniu wysokim ciśnieniem [kPa] } & 900 \\
\hline \multicolumn{2}{|c|}{ 7. wartość 2 ciśn. przy luzowaniu wysokim ciśnieniem [kPa] } & 540 \\
\hline \multicolumn{2}{|c|}{ 8. gradient 1 przy luzowaniu wysokim ciśnieniem [kPa/s] } & 1800 \\
\hline \multicolumn{2}{|c|}{ 9. gradient 2 przy luzowaniu wysokim ciśnieniem [kPa/s] } & 200 \\
\hline \multicolumn{2}{|c|}{ 10. gradient 3 przy luzowaniu wysokim ciśnieniem $[\mathrm{kPa} / \mathrm{s}]$} & 0,25 \\
\hline \multicolumn{2}{|c|}{ 11. progowa wartośc 1 przy luzowaniu wysokim ciśnieniem [kPa] } & 431 \\
\hline \multicolumn{2}{|c|}{ 12. progowa wartośc 2 przy luzowaniu wysokim ciśnieniem [kPa] } & 399 \\
\hline \multicolumn{2}{|c|}{ 13. progowa wartośc 3 przy luzowaniu wysokim ciśnieniem [kPa] } & 367 \\
\hline \multicolumn{2}{|c|}{ 14. czas trwania impulsu 1 przy luzowaniu wysokim ciśnieniem [s] } & 3 \\
\hline \multicolumn{2}{|c|}{ 15. czas trwania impulsu 2 przy luzowaniu wysokim ciśnieniem [s] } & 6 \\
\hline \multicolumn{2}{|c|}{ 16. czas trwania impulsu 3 przy luzowaniu wysokim ciśnieniem [s] } & 9 \\
\hline \multicolumn{2}{|c|}{ 17. czas trwania fazy z ciśnieniem P_LW2 [s] } & 60 \\
\hline \multicolumn{2}{|c|}{ 18. nadwyżka cisnienia nad PN - sposób realizacji stanu G iN [kPa] } & 30 \\
\hline Drukuj & Rezygnuj & Zatwierdź \\
\hline
\end{tabular}

Rys. 13. Okno ustalania parametrów hamowania

\subsection{Realizacja programu badawczego}

Po wybraniu klawisza: Start w oknie zestawów danych (p.3.1) otwiera się okno z rys. 14. Po wybraniu kolejnego klawisza: Start rozpoczyna się realizacja algorytmu programu badawczego.

$\mathrm{W}$ oknie są prezentowane różne elementy związane $\mathrm{z}$ przebiegiem programu. W dolnym panelu są wartości zadane ustalane zgodnie $\mathrm{z}$ przygotowanym zestawem danych i wysyłane do stacji slave realizujących hamowanie. W górnej części okna jest prezentowany aktualny stan węzłów slave (jednocześnie do pięciu węzłów). 


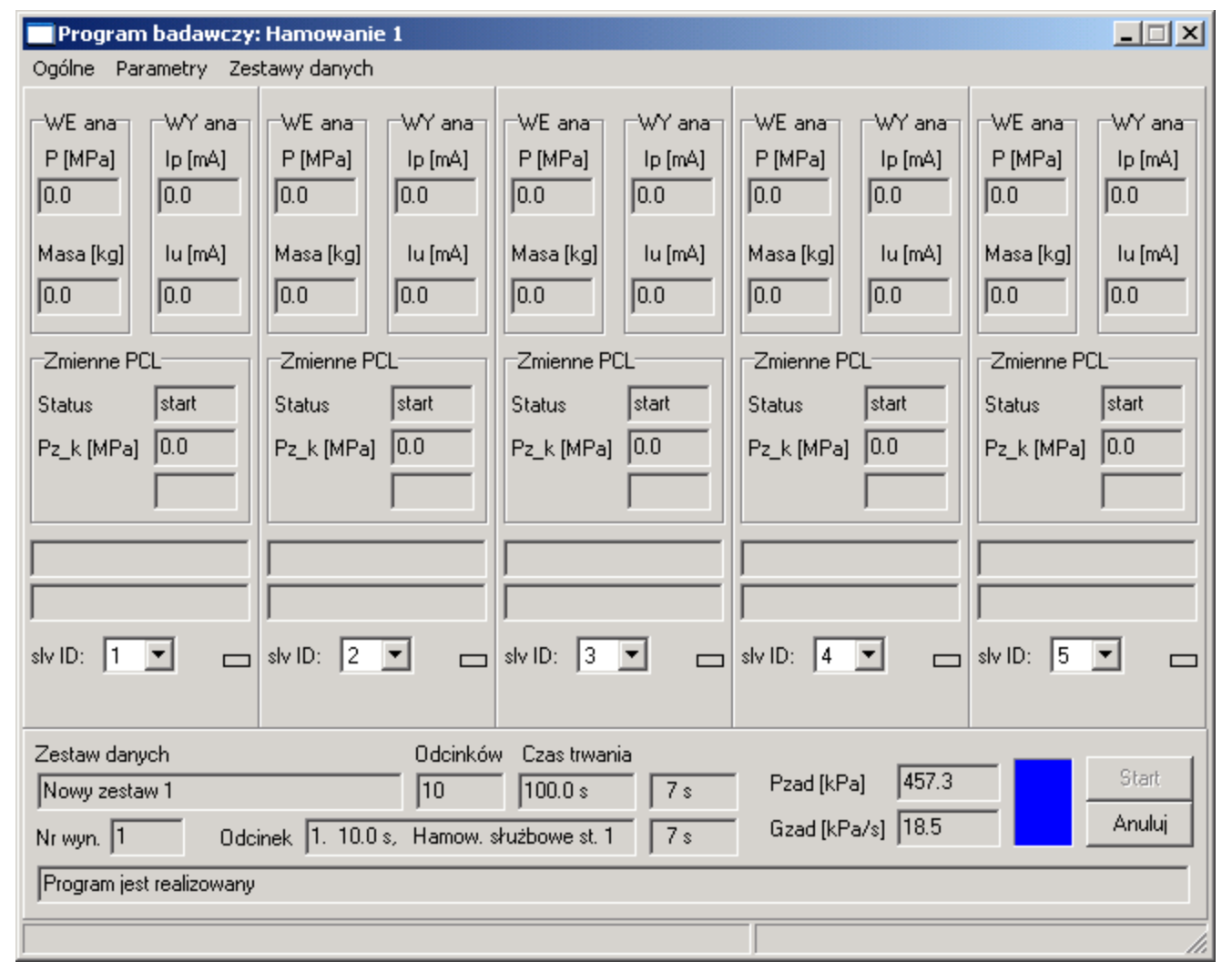

Rys. 14. Okno realizacji programu badawczego.

\section{Podsumowanie}

Przedstawiono program wspierający badanie układu pomiarowo - sterującego pracującego $\mathrm{w}$ sieci CAN open na etapie jego projektowania i uruchamiania. Program umożliwia konfigurację i monitorowanie pracy sieci oraz realizację algorytmów pomiarowo sterujących. Powyższe funkcje pozwalają na badanie różnych wariantów pracy układu przeznaczonego do pojazdów szynowych przed wykonaniem jego wersji docelowej.

\section{Literatura}

[1] Bocian S.: Przyszlościowe wspótbieżne mikroprocesorowe inteligentne systemy mechatroniczne $w$ sterowaniu $i$ diagnostyce pojazdów szynowych (1). Pojazdy Szynowe Nr 4/2007.

[2] Koncepcja układu do badania algorytmów sterujacych $w$ pojazdach szynowych. Opis uktadu sieciowego CANopen. Instytut Pojazdów Szynowych „Tabor”w Poznaniu, OR-9200.

[3] Koncepcja ukladu do badania algorytmów sterujacych $w$ pojazdach szynowychw oparciu o sieć CANopen. Program testowy algorytmów sterujacych. Instytut Pojazdów Szynowych ,Tabor” w Poznaniu, OR-9280.

[4] CANopen. Application Layer and Communication Profile. CiA Draft Standard 301. CAN in Automation, Am Weichselgarten 26, D-91058 Erlangen, 2002, www.can-cia.org

[5] CANopen. Device Profile for Generic I/O Modu-les. CiA Draft Standard 401. CAN in Automation, Am Weichselgarten 26, D-91058 Erlangen, Version 2.1, 2002, www.can-cia.org 